7. Pitak-Arnnop P, Schouman T, Bertrand JC, Hervé C. Comment éviter la non-conformité de la recherche biomédicale? Recommandations aux chirurgiens. J Chir (Paris) 2008;145:534-41.

8. Altman DG, Bland JM. Absence of evidence is not evidence of absence. BMJ 1995;311:485.

9. Rehman KU, Parmar S, Williams R, Dover S, Lalani El-N. Research training for oral and maxillofacial surgery. Br J Oral Maxillofac Surg 2008;46:343.

10. Trikalinos NA, Evangelou E, Ioannidis JP. Falsified papers in high-impact journals were slow to retract and indistinguishable from nonfraudulent papers. J Clin Epidemiol 2008;61:464-70.

11. Wager E, Fiack S, Graf C, Robinson A, Rowlands I. Science journal editors' views on publication ethics: Results of an international survey. J Med Ethics 2009;35:348-53.

12. Nath SB, Marcus SC, Druss BG. Retractions in the research literature: misconduct or mistakes? Med J Aust 2006;185:152-4.

13. Atlas MC. Emerging ethical issues in instructions to authors of high-impact biomedical journals. J Med Libr Assoc 2003;91: 442-9.

14. Sorinola O, Olufowobi O, Coomarasamy A, Khan KS. Instructions to authors for case reporting are limited: a review of a core journal list. BMC Med Educ 2004;4:4.

15. Rohrich RJ. Ethical approval of clinical studies, informed consent, and the declaration of Helsinki: what you need to know. Plast Reconstr Surg 2007;119:2307-9.

16. Gilbert FJ, Denison AR. Research misconduct. Clin Radiol 2003;58:499-504.

17. Benninger MS, Jackler RK, Johns MM, Johnson JT, Kennedy DW, Ruben RJ, et al. Consortium of otolaryngology- head and neck surgery journals to collaborate in maintenance of high ethical standards. Arch Otolaryngol Head Neck Surg 2005; 131:381-2.

18. Johnson JT, Niparko JK, Levine PA, Kennedy DW, Weber PC, Weber RS, et al. Standards for ethical publication. Arch Otolaryngol Head Neck Surg 2007;133:7-8.

19. Pitak-Arnnop P, Hemprich A, Dhanuthai K, Pausch NC. Ethical conduct of human research: some controversies. Otolaryngol Head Neck Surg 2010;143:469-70.

doi:10.1016/j.tripleo.2010.10.001

\section{Association of oral lichen planus with thyroid disease in a Finnish population: A retrospective case- control study: "A different finding from a Mediterranean area"}

\section{To the Editor:}

Siponen et al. ${ }^{1}$ report an association of oral lichen planus/oral lichenoid lesions (OLP/OLL) with thyroid disease in the Finnish population. As they point out, OLP has been associated with a number of systemic disorders, generally of autoimmune origin (myasthenia gravis, Sjögren's syndrome, ulcerative colitis, psoriasis, celiac disease, some liver diseases, thymoma, and lupus erythematosus); however, only in a few conditions has this link been confirmed. ${ }^{2-6}$ For example, the correlation between chronic hepatitis $\mathrm{C}$ virus (HCV) infection and OLP would be one of these, even if many contrasting results have been published, ${ }^{7-14}$ and the partial dependency on geographic factors as well as genetic differences has been focused. ${ }^{15,16}$ Furthermore, autoimmune conditions, such as systemic lupus erythematosus, rheumatoid arthritis, and celiac disease have also been simply found to be associated with autoimmune thyroid diseases, ${ }^{17}$ but without great and definitive evidence.

Hence, the association between OLP/OLL and thyroid diseases/thyroid medication, in particular hypothyroidism, have been reported in some studies ${ }^{18-20}$ up to the recent study by Siponen et al.," who analyzed retrospectively 222 OLP/OLL patients and 222 controls, with a marginal significant association (95\% confidence interval $[\mathrm{CI}]=1.03$ to 4.90 ) between OLP/ OLL and hypothyroidism (10\% versus $5 \%$ in controls). Finally, the authors suggested that the association of OLP and hypothyroidism could be linked to a similar, but still unknown, immune-mediated mechanism, warranting further studies in a different population.

With this regard, we would like to share our findings from a cross-sectional study performed in Sicily (West Mediterranean area). We consecutively recruited 125 resident patients, of these 74 had Hashimoto's thyroiditis or Graves disease ( 70 female and 4 male; mean age: $47 \pm 15.2$ years; range: 14 to 79 years; of which 58 patients had Hashimoto's thyroiditis and 16 had Graves disease) as the test group; these 2 autoimmune pathologies share with OLP a common immune-mediated pathogenesis, causing hypothyroidism and hyperthyroidism, respectively. Controls were 51 patients (42 female; 9 male; mean age: $54.6 \pm 11.5$ years; range: 24 to 73 years) suffering from goiter, an endemic disease in Sicily without autoimmune pathogenesis, ${ }^{21}$ and were found to be matched for age and gender with the test group $(P>.2$ by Student $t)$.

In all samples, thyroid diseases were diagnosed both serologically and histologically; all patients underwent total thyroidectomy and subsequent replacement with thyroxin medication. All patients underwent oral examination, independently, by 2 of the authors (C.D. and C. P.), both experts in oral medicine. In our study, all patients who were HCVpositive or with OLL potentially associated with drugs, ${ }^{22}$ amalgam fillings, or topical allergens were excluded, different from Siponen et al., ${ }^{1}$ to reduce biases on the final results.

One patient with Hashimoto's thyroiditis showed oral lesions with a reticular aspect bilaterally on the buccal mucosa and atrophic/erosive features on the masticatory mucosa, compatible with the diagnosis of OLP. The patient underwent incisional oral biopsy and the subsequent histologic examination confirmed the diagnosis of OLP. None of the controls showed clinical signs of OLP/OLL.

Different from Siponen et al., ${ }^{1}$ we did not find any significant association between autoimmune thyroid 
diseases and OLP or between thyroxin drug use and OLL, presumptively high because of the endemic status of thyroid diseases in our population and the consequent use of thyroxine-based drugs.

In conclusion, with regard to the findings by Siponen et al., ${ }^{1}$ we do not think that the data to date show definitively an association between OLP/OLL and, at least, hypothyroidism, especially with the potential for biases from sample size calculation and consequently from type I error.

Domenico Compilato, DDS, $P h D^{a}$ Carlo Paderni, DDS, $P h D^{a}$ Olga Di Fede, DDS, PhD ${ }^{a}$ Gaspare Gulotta, $M D^{b}$ Giuseppina Campisi, DDS ${ }^{a}$

${ }^{a}$ Department of Surgical and Oncological Disciplines Section of Stomatological Sciences ${ }^{b}$ Department of Surgical Oncological Disciplines

Section GENURTO

\section{REFERENCES}

1. Siponen M, Huuskonen L, Laara E, Salo T. Association of oral lichen planus with thyroid disease in a Finnish population: a retrospective case-control study. Oral Surg Oral Med Oral Pathol Oral Radiol Endod 2010;110:319-24.

2. Gruppo Italiano Studi Epidemiologici in Dermatologia (GISED). Lichen planus and liver diseases: a multicentre case-control study. BMJ 1990;300(6719):227-30.

3. Gruppo Italiano Studi Epidemiologici in Dermatologia (GISED). Study of lichen planus conducted by the IGESD: results, implications for clinical practice, prospects. G Ital Dermatol Venereol 1990;125(12):563-7.

4. Gruppo. Italiano Studi Epidemiologici in Dermatologia (GISED). Epidemiological evidence of the association between lichen planus and two immune-related diseases. Alopecia areata and ulcerative colitis. Arch Dermatol 1991;127:688-91.

5. Scully C, Beyli M, Ferreiro MC, Ficarra G, Gill Y, Griffiths M, et al. Update on oral lichen planus: etiopathogenesis and management. Crit Rev Oral Biol Med 1998;9:86-122.

6. Scully C, Porter SR, Eveson JW. Oral lichen planus and coeliac disease. Lancet 1993;341:1660.

7. Bagan JV, Aguirre JM, del Olmo JA, Milian A, Penarrocha M, Rodrigo JM, et al. Oral lichen planus and chronic liver disease: a clinical and morphometric study of the oral lesions in relation to transaminase elevation. Oral Surg Oral Med Oral Pathol 1994;78:337-42.

8. Campisi G, Di Fede O, Craxi A, Di Stefano R, Margiotta V. Oral lichen planus, hepatitis $\mathrm{C}$ virus, and HIV: no association in a cohort study from an area of high hepatitis $\mathrm{C}$ virus endemicity. J Am Acad Dermatol 2004;51:364-70.

9. Campisi G, Fedele S, Lo Russo L, Di Fede O, Arico P, Craxi A, et al. HCV infection and oral lichen planus: a weak association when HCV is endemic. J Viral Hepat 2004;11:465-70.

10. Carrozzo M, Gandolfo S, Carbone M, Colombatto P, Broccoletti $\mathrm{R}$, Garzino-Demo $\mathrm{P}$, et al. Hepatitis $\mathrm{C}$ virus infection in Italian patients with oral lichen planus: a prospective case-control study. J Oral Pathol Med 1996;25:527-33.

11. Friedrich RE, Heiland M, El-Moawen A, Dogan A, von Schrenck T, Loning T. Oral lichen planus in patients with chronic liver diseases. Infection 2003;31:383-6.

12. Klanrit P, Thongprasom K, Rojanawatsirivej S, Theamboonlers A, Poovorawan Y. Hepatitis $\mathrm{C}$ virus infection in Thai patients with oral lichen planus. Oral Dis 2003;9:292-7.

13. Lodi G, Giuliani M, Majorana A, Sardella A, Bez C, Demarosi
F, et al. Lichen planus and hepatitis $\mathrm{C}$ virus: a multicentre study of patients with oral lesions and a systematic review. $\mathrm{Br} \mathrm{J}$ Dermatol 2004;151:1172-81.

14. Nagao Y, Sata M, Tanikawa K, Itoh K, Kameyama T. Lichen planus and hepatitis $\mathrm{C}$ virus in the northern Kyushu region of Japan. Eur J Clin Invest 1995;25:910-4.

15. Carrozzo M, Francia Di Celle P, Gandolfo S, Carbone M, Conrotto D, Fasano ME, et al. Increased frequency of HLA-DR6 allele in Italian patients with hepatitis $\mathrm{C}$ virus-associated oral lichen planus. Br J Dermatol 2001;144:803-8.

16. Eisen D, Carrozzo M, Bagan SJV, Thongprasom K, Number V. Oral lichen planus: clinical features and management. Oral Dis 2005; 11:338-49.

17. Lazurova I, Benhatchi K, Rovensky J, Kozakova D, Wagnerova $\mathrm{H}$, Tajtakova M, et al. Autoimmune thyroid disease and autoimmune rheumatic disorders: a two-sided analysis. Ann N Y Acad Sci 2009;1173:211-6.

18. Kragelund C, Thomsen CE, Bardow A, Pedersen AM, Nauntofte $\mathrm{B}$, Reibel J, et al. Oral lichen planus and intake of drugs metabolized by polymorphic cytochrome P450 enzymes. Oral Dis 2003;9:177-87.

19. Dreiher J, Shapiro J, Cohen AD. Lichen planus and dyslipidaemia: a case-control study. Br J Dermatol 2009;161:626-9.

20. Chang JY, Chiang CP, Hsiao CK, Sun A. Significantly higher frequencies of presence of serum autoantibodies in Chinese patients with oral lichen planus. J Oral Pathol Med 2009; 38:48-54.

21. Vigneri R. Studies on the goiter Endemia in Sicily. J Endocrinol Invest 1988;11:831-43.

22. Scully C, Bagan JV. Adverse drug reactions in the orofacial region. Crit Rev Oral Biol Med 2004;15:221-39.

doi:10.1016/j.tripleo.2010.09.074

\section{Association of oral lichen planus with thyroid disease in a Finnish population: A retrospective case control study: "A different finding from a Mediterranean area"}

In reply:

We thank Dr Compilato et al. for their interest in our study and for sharing their own findings. We also fully agree with their statement " . . . we do not think the data to date show definitively an association between OLP/ OLL and, at least, hypothyroidism" up to this point. Nothing in our article indicates a different conclusion; yet, we are unable to follow their argument to the end. For example, the meaning of "bias from sample size calculation" remains obscure to us, such a bias not being described in any well-known textbook on epidemiologic methods. Therefore, we would like to elaborate some methodological issues that we consider essential when evaluating observational evidence provided either by any single study, including theirs and ours, or jointly by several independent studies on the same question.

A major problem encountered in any epidemiologic study addressing the existence, direction, and strength of a conceivable association between thyroid diseases 